\title{
Quantity over Quality? Perception of Designating Long-Term Care Hospitals as Providers of Hospice and Palliative Care
}

\author{
Yaeji Kim-Knauss, M.A., Eunseok Jeong, M.A.*, Jin-ah Sim, Ph.D., Jihye Lee, R.N., M.S. ${ }^{\dagger}$, \\ Jiyeon Choo, R.N. ${ }^{\ddagger}$ and Young Ho Yun, M.D., Ph.D.**,
}

Cancer Research Institute, Seoul National University, Departments of *Family Medicine, ${ }^{\dagger}$ Biomedical Informatics and

${ }^{\ddagger}$ Biomedical Science, Seoul National University College of Medicine, Seoul, Korea

Purpose: Amendment to the Act on Decisions on Life-sustaining Treatment was recently enacted to designate long-term care hospitals as providers of hospice and palliative care. Despite its benefit of providing improved accessibility to end-of-life care, the amendment has raised concerns about its effect on quality of service. This study aimed to use information obtained from an expert group interview and previous studies to compare how cancer patients, family caregivers, physicians, and the general Korean population perceive the potential benefits and risks of this amendment. Methods: We conducted a multicenter crosssectional study from July to October 2016. The included participants answered a structured questionnaire regarding the extent to which they agree or disagree with the questionnaire items indicating the potential benefits and risks of the amendment. Chi-square tests and univariate and multivariate logistic regression analyses were performed. Results: Compared with the general population, physicians agreed more that long-term care hospitals are currently not adequately equipped to provide quality hospice and palliative care. Family caregivers found improved access to long-term care hospitals more favorable but were more likely to agree that these hospitals might prioritize profits, thereby threatening the philosophy of hospice care, and that families might cease to fulfill filial responsibilities. Compared with the general population, cancer patients were more concerned about the potentially decreased service quality in this setting. Conclusion: Although potential service beneficiaries and providers expected improved accessibility of hospice and palliative care services, they were also concerned whether the system can provide adequate quality of end-of-life care.

Key Words: Hospice care, Palliative care, Terminal care, Health personnel, Caregivers
Received November 9, 2018

Revised July 23, 2019

Accepted September 4, 2019

\section{INTRODUCTION}

Enactment of the Act on Hospice and Palliative Care and Decisions on Life-sustaining Treatment for Patients at the End of Life in 2016 (Act no. 14013) has enlightened the Korean public about a fairly advanced concept of good death and heralded a considerable change in people's attitude toward this topic. Although patients nearing the end of life are now entitled to receive hospice and palliative care covered by the National Health Insurance Service, the matter of accessibility to such services remains unresolved (1). To this end, long-term care hospitals, which are major and commonly used chronic care facilities in Korea, were recently designated in February 2018 as providers of hospice and palliative care. However, this 
amendment may have benefits and risks, especially regarding the quality of end-of-life care service $(2,3)$. Based on the current situation and information from previous studies about the services provided by long-term care hospitals and the related concerns (2-6), we aimed to examine how potential providers and beneficiaries of hospice and palliative care perceive this amendment by focusing on its benefits and risks.

The European Association for Palliative Care suggests that $\geq$ 50 beds are needed in hospice and palliative care facilities for a population of 1 million, indicating that there should be $\geq$ 2,557 beds to cover the Korean population (7). However, the statistics released by the National Care Center reported that only 1,302 beds have been allocated by such facilities, which covers less than half of the required number of beds. These numbers raise concerns that patients in Korea are less likely to receive specialized comfort end-of-life care despite the advanced statutory basis and growing consensus on dying well. Considering these concerns about accessibility, long-term care hospitals have been newly designated as providers of hospice and palliative care, which may have been inspired by the integrative long-term care services in Belgium, Denmark, and Iceland (8).

In Korea, a long-term care hospital is a major and common non-acute facility that specializes in chronic care. The roles of long-term care hospitals and other major facilities for chronic care in Korea (i.e., hospice and palliative care facilities as well as long-term nursing homes) are distinguishable at least in statutory terms (Table 1).

However, it should be noted that the difference between long-term care hospitals and hospice and palliative care facilities appears somewhat ambiguous in practice (9-11), which in fact legitimizes the current amendment. For instance, the total number of cancer patients at long-term care hospitals was 35,000 in 2014, which was the third largest after tertiary and general hospitals in the same year (10). Moreover, the residents of nursing homes are commonly referred to long-term care hospitals when nearing the end of life. These circumstances inevitably require such hospitals to provide not only curative medical treatment but also proper hospice and palliative care (9). According to the Korean Statistical Information, 1,372 long-term care hospitals were available in 2015, which is 20 times higher than the number of designated hospice and palliative care facilities in the same year. Consequently, designating long-term care hospitals as providers of hospice and palliative care seems to be essential to fill the gap between the supply and demand of medical resources.

Nonetheless, potential challenges regarding the quality of end-of-life care provided by long-term care hospitals should not be overlooked. For example, a study by the National Human Rights Commission of Korea pointed out a lack of health professionals and facilities, provision of excessive and unnecessary services, and an unsanitary environment as major concerns (2). Furthermore, long-term care hospitals may not meet the needs of end-of-life patients and their family caregivers

Table 1. Different Roles of the 3 Major Facilities for Care of Chronic Patients in Korea.

\begin{tabular}{|c|c|c|c|}
\hline & Long-term care hospitals & Hospice and palliative care facilities & Long-term nursing homes \\
\hline Statutory base & Medical Service Act (Act no. 14438)* & $\begin{array}{l}\text { Act on Hospice and Palliative Care and } \\
\text { Decisions on Life-sustaining Treatment for } \\
\text { Patients at the End of Life (Act no. 14013)* }\end{array}$ & $\begin{array}{l}\text { Long-term Care Insurance Act } \\
\qquad \text { (Act no. 14321)* }\end{array}$ \\
\hline Recipients & $\begin{array}{l}\text { Patients with geriatric illness or chronic } \\
\text { disease such as cancer and dementia } \\
\text { or undergoing recovery after surgery or } \\
\text { injury }\end{array}$ & $\begin{array}{l}\text { Cancer patients and non-cancer patients such } \\
\text { as those with HIV/AIDS, COPD, and chronic } \\
\text { liver cirrhosis at the terminal stage }\end{array}$ & $\begin{array}{l}\text { Older adults entitled to long-term care } \\
\text { upon investigation for grading }\end{array}$ \\
\hline Benefits & $\begin{array}{l}\text { Providing medical services and physical } \\
\text { therapy for inpatients and outpatients }\end{array}$ & $\begin{array}{l}\text { Providing holistic intervention that includes } \\
\text { pain and symptom management as well as } \\
\text { mental, spiritual, and bereavement care }\end{array}$ & $\begin{array}{l}\text { Providing physical assistance or } \\
\text { educational/training programs to } \\
\text { maintain mental and physical functions }\end{array}$ \\
\hline Insurance coverage & Yes & Yes & Yes \\
\hline Primary care provider & $\begin{array}{l}\text { Physicians, nurses, caregivers, and physical } \\
\text { therapists }\end{array}$ & Physicians, nurses, and social workers & $\begin{array}{l}\text { Long-term caregivers, nurses, and social } \\
\text { workers }\end{array}$ \\
\hline
\end{tabular}

*Source: elaw.klri.re.kr [Internet]. Sejong: Korea Law Translation Center; c2019 [cited 2018 Nov 9]. Available from: http://elaw.klri.re.kr/kor_service/main.do. COPD: Chronic Obstructive Pulmonary Disease. 
given that these hospitals have no history of providing essential hospice and palliative care services such as comprehensive comfort care, terminal care, and bereavement management (3). Although increasing the access to hospice and palliative care is a timely and important issue in the Korean society, statutory reform may not benefit patients and their caregivers without considering the quality of end-of-life care.

Taken together, we suggest that the amendment designating long-term care hospitals as providers of hospice and palliative care has potential benefits and risks that should be taken into account before the amendment takes effect. Obtaining the opinions of potential beneficiaries and service providers may provide better insights into the successful expansion of hospice and palliative care. The study aim was to determine the extent to which cancer patients, family caregivers, physicians, and the general population agree or disagree with the perceived benefits and risks of the amendment to the Act on Hospice and Palliative Care and Decisions on Life-sustaining Treatment for Patients at the End of Life.

\section{METHODS}

\section{Participants}

We conducted a multicenter cross-sectional study from July to October 2016 with the following participant groups: cancer patients, family caregivers, physicians, and general population. World Research, Inc. (Seoul, Korea), a survey company specializing in the field of oncology, was consulted on the overall design of this study and survey. The study was approved by the Institutional Review Board (IRB) of the Seoul National University Hospital as an IRB review exemption study (IRB no. E-1607-107-777). A total of 3,940 individuals participated in our study.

\section{1) Cancer patients}

The oncologists participating in this research identified adult clinic patients (>18 years) from 12 general hospitals that we could recruit for the study. Among the 6,024 identified patients, we included those who had no problem communicating with the research assistants for an unbiased survey, filling out the questionnaire, and understanding the study intent. The fi- nal sample comprised 1,001 eligible patients (16.6\% response rate), and all of them provided informed consent.

\section{2) Family caregivers}

The patients initially contacted for our study identified their relative who had been providing them with the most assistance. The identified family caregivers were informed about the study intent, and among the 5,017 contacted caregivers, we included a total of 1,006 eligible family caregivers who provided informed consent and completed the survey $(20.1 \%$ response rate).

\section{3) Physicians}

We performed an online-based survey of physicians from 12 general hospitals and local clinics through the Korean Medical Association (KMA). To make our sample more representative, the analytical results of physicians were weighted according to age and sex distribution based on the membership statistics provided by KMA. Among the 928 physicians who completed the online survey (30\% response rate), internal medicine was practiced by most physicians (27.2\%) followed by family medicine (10\%) and radiology (5.9\%). Analysis of the participants' specific occupations showed that $39.5 \%$ (highest) of the respondents were medical school professors.

\section{4) General population}

Individuals from 17 major cities and local districts sampled from age and sex strata in accordance with the 2015 Census of Korea were interviewed. For the final sample selection, we applied probability proportional to size, which is known to be effective for obtaining a representative national sample, especially when the sample groups vary in size (12). Among the 10,000 individuals contacted initially, 1,005 participants (age range: 20 70 years) who agreed to participate in the survey (10\% response rate) were included as our final sample. We used a structured questionnaire, and trained researchers assisted in conducting the survey.

\section{Measurements}

\section{1) Questionnaire and items}

Drawing on an expert group interview and previous studies about the quality of end-of-life care services provided 
by long-term care hospitals $(2,3)$, we generated the survey items indicating the potential benefits and risks of the current amendment. We first informed the participants that long-term care hospitals would be designated as hospice palliative facilities from February 2018 and asked what they thought about the following statements regarding this issue: "long-term care hospitals would be properly equipped to provide hospice and palliative care (item 1)", "long-term care hospitals would have better accessibility (item 2)", "long-term care hospitals would provide improved care (item 3)", "long-term care hospitals would pursue profit and threaten the philosophy of hospice care (item 4)", "long-term care hospitals would make families irresponsible with patient care (item 5)", and "long-term care hospitals would charge unnecessary expenses (item 6)". The first 3 items reflected positively valent opinions about the current amendment, whereas the last 3 items assessed negatively valent opinions.

\section{2) Item measurement}

Because this study aimed to determine if there are differences in the percentages of participants from each group who agreed or disagreed with the study statements, we dichotomized the original answers that were rated on a 4-point Likert scale with anchors of " $1=$ strongly disagree" to " $4=$ strongly agree" into " $1=$ agree" and " $0=$ disagree". The Kaiser - Meyer - Olkin criterion was set at 0.68 , and Bartlett's test of sphericity was significant $(\mathrm{P}<0.001)$, which indicates moderate sampling adequacy and, therefore, suggests that the use of explanatory factor analysis (EFA) was suitable. Using EFA, 2 factors were extracted explaining $51 \%$ of the total variance. Factor 1 comprised the 3 positively valent items (i.e., items 1 , 2, and 3 ) that explained $28 \%$ of the variance with factor loadings from 0.61 to 0.88 , whereas factor 2 comprised the 3 negatively valent items (i.e., items 4, 5, and 6) that explained $23 \%$ of the variance with factor loadings from 0.66 to 0.69 . Cronbach' $\mathrm{s}$ alpha for this measure was 0.67 , representing a moderatelevel internal consistency of the 6 items. We collected sociodemographic variables of the participants such as sex, age, and educational level.

\section{Statistical analysis}

We first examined the distribution of responses to the 6 items and performed a chi-square test to determine if there were any significant differences among the 4 study groups. Then, we performed univariate logistic regression analyses to estimate the crude odds ratio (OR) for each item. The reported OR is the extent to which belonging to a certain group increases or decreases the probability of agreeing to the potential benefits and risks of the current amendment. A value of $>1$ indicates how much more likely it is for an individual to agree with a statement, whereas that of $<1$ means the opposite. We tested different answers across the 4 groups by including them as 3 dummy variables with the general population as the reference group. In addition, we used univariate logistic models with age $(<49=0, \geq 50=1)$, sex (male=0, female=1), and educational level (middle school degree or lower $=0$, high school degree or higher=1) as explanatory variables. We selected the variables that showed significant effects on the answer for each item ( $P$

Table 2. Sample Descriptive Statistics across the 4 Study Groups.

\begin{tabular}{|c|c|c|c|c|c|}
\hline \multirow{2}{*}{ Variable } & $\begin{array}{l}\text { General population } \\
\mathrm{N}=1005\end{array}$ & $\begin{array}{l}\text { Cancer patients } \\
\mathrm{N}=1001\end{array}$ & $\begin{array}{l}\text { Family caregivers } \\
\qquad \mathrm{N}=1006\end{array}$ & $\begin{array}{l}\text { Physicians (unweighted) } \\
\text { N=928 }\end{array}$ & $\begin{array}{l}\text { Physicians (weighted) } \\
\text { N=928 }\end{array}$ \\
\hline & $\mathrm{n}(\%)$ & $\mathrm{n}(\%)$ & $\mathrm{n}(\%)$ & $\mathrm{n}(\%)$ & $\mathrm{n}(\%)$ \\
\hline \multicolumn{6}{|l|}{ Sex } \\
\hline Male & $494(49.2)$ & $390(39.0)$ & $324(32.2)$ & $565(60.9)$ & 707 (76.2) \\
\hline Female & $511(50.8)$ & $610(61.0)$ & $682(67.8)$ & $363(39.1)$ & $221(23.8)$ \\
\hline \multicolumn{6}{|l|}{ Age (yr) } \\
\hline$<49$ & $575(57.2)$ & $334(33.4)$ & $596(59.2)$ & 834 (89.9) & $617(63.4)$ \\
\hline$\geq 50$ & $430(42.8)$ & $667(66.6)$ & 409 (40.8) & $94(10.1)$ & $311(33.6)$ \\
\hline \multicolumn{6}{|l|}{ Educational level } \\
\hline Middle school degree or less & $152(15.2)$ & $205(20.5)$ & $75(7.5)$ & $0(0)$ & $0(0)$ \\
\hline High school degree or higher & $849(84.8)$ & $796(79.5)$ & $931(92.5)$ & $928(100.0)$ & $928(100.0)$ \\
\hline
\end{tabular}


$<0.05$ ) and included them as explanatory variables for the corresponding multivariate logistic regression models. The final analysis was to investigate whether belonging to a certain group was still associated with the dependent variables, namely, the 6 statements regarding the current amendment even after controlling for the effects of the other covariates. We calculated the adjusted OR (aOR), which is the OR value with the controlled effects of the other explanatory variables included in the same model. We used the R package "weights" to test weighted chi-square statistics (13) and the R function $\mathrm{glm}$, a tool for building a generalized linear model, to fit logistic regression models.

\section{RESULTS}

\section{Sample characteristics}

The sociodemographic characteristics of our study sample are presented in Table 2. In the patient group, 610 patients were female $(61.0 \%)$ and $66.6 \%$ were aged $>49$ years. Regarding the educational level, $79.5 \%$ of the patients had a high school degree or higher degree, indicating that the majority of our patient sample was highly educated. Among family caregivers, there were $67.8 \%$ females, $40.8 \%$ were aged $>49$ years, and $92.5 \%$ had a high school degree or higher degree. Regarding physicians, we assigned a weighted score to match the sex and age proportion of our sample with its actual distribution as reported by KMA. Originally, $60.9 \%$ of the physicians were males and $89.9 \%$ were aged $<50$ years, but after we assigned the weight score, the proportion of males increased to $76.2 \%$, whereas the proportion of participants aged $<50$ years decreased to $63.4 \%$. Lastly, the general population had $50.8 \%$ females, with $42.8 \%$ being aged $>49$ years and $84.8 \%$ having a high school degree or higher degree.

\section{Differences in opinions across the 4 study groups}

The proportions of respondents who agreed to the statements regarding the hospice and palliative care provided by long-term care hospitals are presented in Table 3. The general population, cancer patients, family caregivers, and physicians appeared to have differences in opinions about the 6 items. For items 1 (long-term care hospitals would be properly equipped to provide hospice and palliative care), 3 (long-term care hospitals would provide improved care), and 6 (long-term care hospitals would charge unnecessary expenses), the physicians reported notably lower levels of agreement than the others (item 1: $\chi^{2}=462.79, \mathrm{df}=3, \mathrm{P}<0.001 ;$ item $3: \chi^{2}=202.70, \mathrm{df}=3, \mathrm{P}$ $<0.001$; item $\left.6: x^{2}=64.82, \mathrm{df}=3, \mathrm{P}<0.001\right)$. Family caregivers were more likely to agree with item 2 (long-term care hospitals would have better accessibility) and item 5 (long-term care hospitals would make families irresponsible with patient care) than the others (item 2: $\chi^{2}=22.24, \mathrm{df}=3, \mathrm{P}<0.001$; item 5: $x^{2}=17.36, \mathrm{df}=3, \mathrm{P}<0.001$ ). Regarding item 4 (long-term care hospitals would pursue profit and threaten the philosophy of hospice care), physicians were more likely to agree with the statement than the others, whereas the general population

Table 3. Proportion of the Population that Agrees with the Current Amendment across the 4 Study Groups and Chi-square Values for Group Comparison.

\begin{tabular}{|c|c|c|c|c|c|c|c|c|c|c|}
\hline & \multicolumn{2}{|c|}{$\begin{array}{l}\text { General population** } \\
\qquad N=1,005\end{array}$} & \multicolumn{2}{|c|}{$\begin{array}{l}\text { Cancer patients** } \\
\qquad \mathrm{N}=1,001\end{array}$} & \multicolumn{2}{|c|}{$\begin{array}{l}\text { Family caregivers** } \\
\qquad N=1,006\end{array}$} & \multicolumn{2}{|c|}{$\begin{array}{l}\text { Physicians (weighted)** } \\
\qquad N=928\end{array}$} & \multirow{2}{*}{$x^{2}(d f)$} & \multirow{2}{*}{ P-value } \\
\hline & $\mathrm{n}$ & $\%$ & $n$ & $\%$ & $n$ & $\%$ & $n$ & $\%$ & & \\
\hline Item $1 *$ & 656 & 65.3 & 658 & 65.7 & 698 & 69.4 & 253 & 27.3 & $462.79(3)$ & $<0.001$ \\
\hline Item $2^{\dagger}$ & 733 & 72.9 & 752 & 75.1 & 796 & 79.1 & 682 & 73.5 & $22.24(3)$ & $<0.001$ \\
\hline${\text { Item } 3^{\ddagger}}^{\ddagger}$ & 693 & 69.0 & 650 & 64.9 & 701 & 69.7 & 374 & 40.3 & 202.70 (3) & $<0.001$ \\
\hline Item $4^{\S}$ & 730 & 72.6 & 786 & 78.5 & 789 & 78.4 & 768 & 82.8 & $18.73(3)$ & $<0.001$ \\
\hline |tem 5" & 686 & 68.3 & 688 & 68.7 & 735 & 73.1 & 608 & 65.5 & $17.36(3)$ & $<0.001$ \\
\hline Item 6" & 844 & 84.0 & 860 & 85.9 & 831 & 82.6 & 691 & 74.5 & $64.82(3)$ & $<0.001$ \\
\hline
\end{tabular}

* Long-term care hospitals would be properly equipped to provide hospice and palliative care, ${ }^{\dagger}$ Long-term care hospitals would have better accessibility, ${ }^{\dagger}$ Longterm care hospitals would provide improved care, "Long-term care hospitals would pursue profit and threaten the philosophy of hospice care, "Long-term care hospitals would make families irresponsible with patient care, "Long-term care hospitals would charge unnecessary expenses, **The proportion of participants who responded "strongly agree" or "agree" to each question. Chi-square test.

df: degree of freedom. 


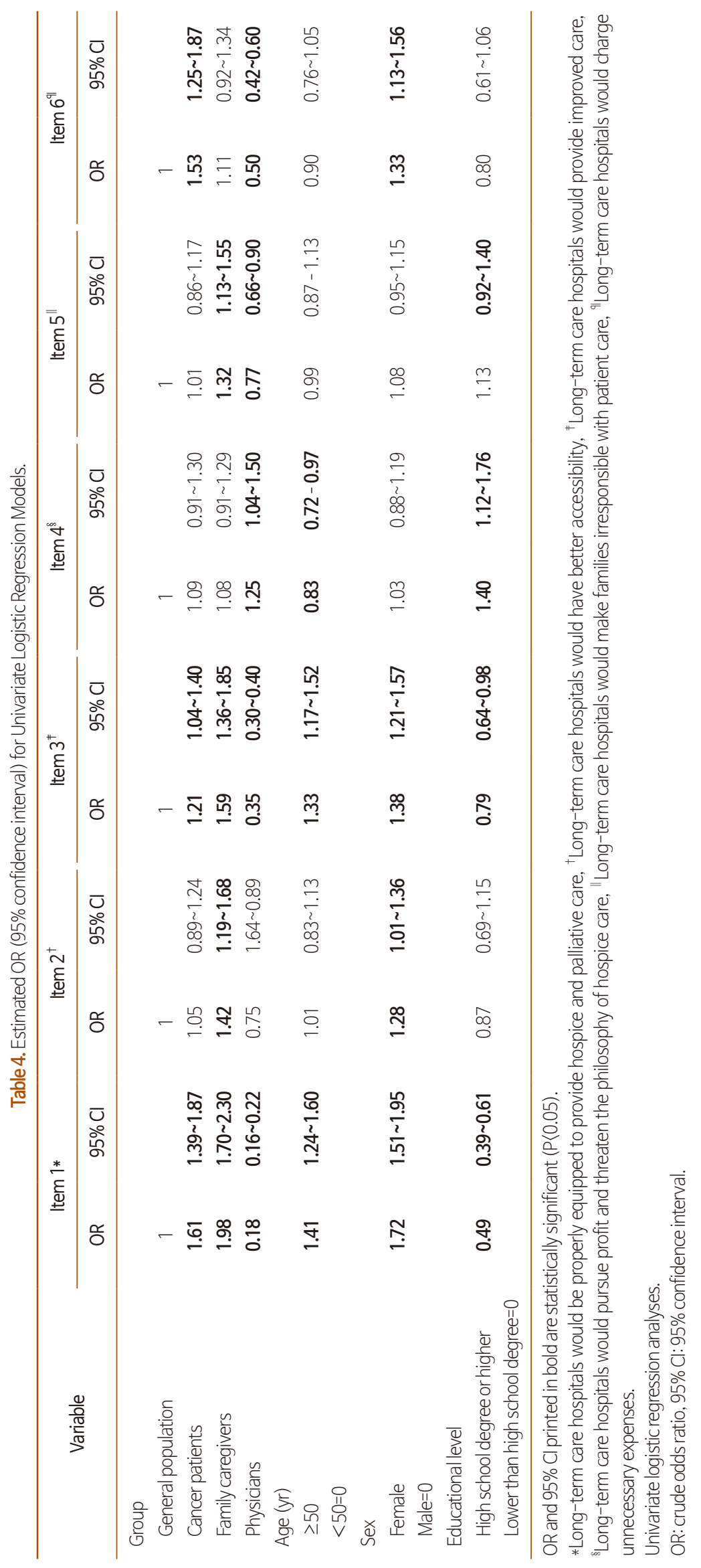




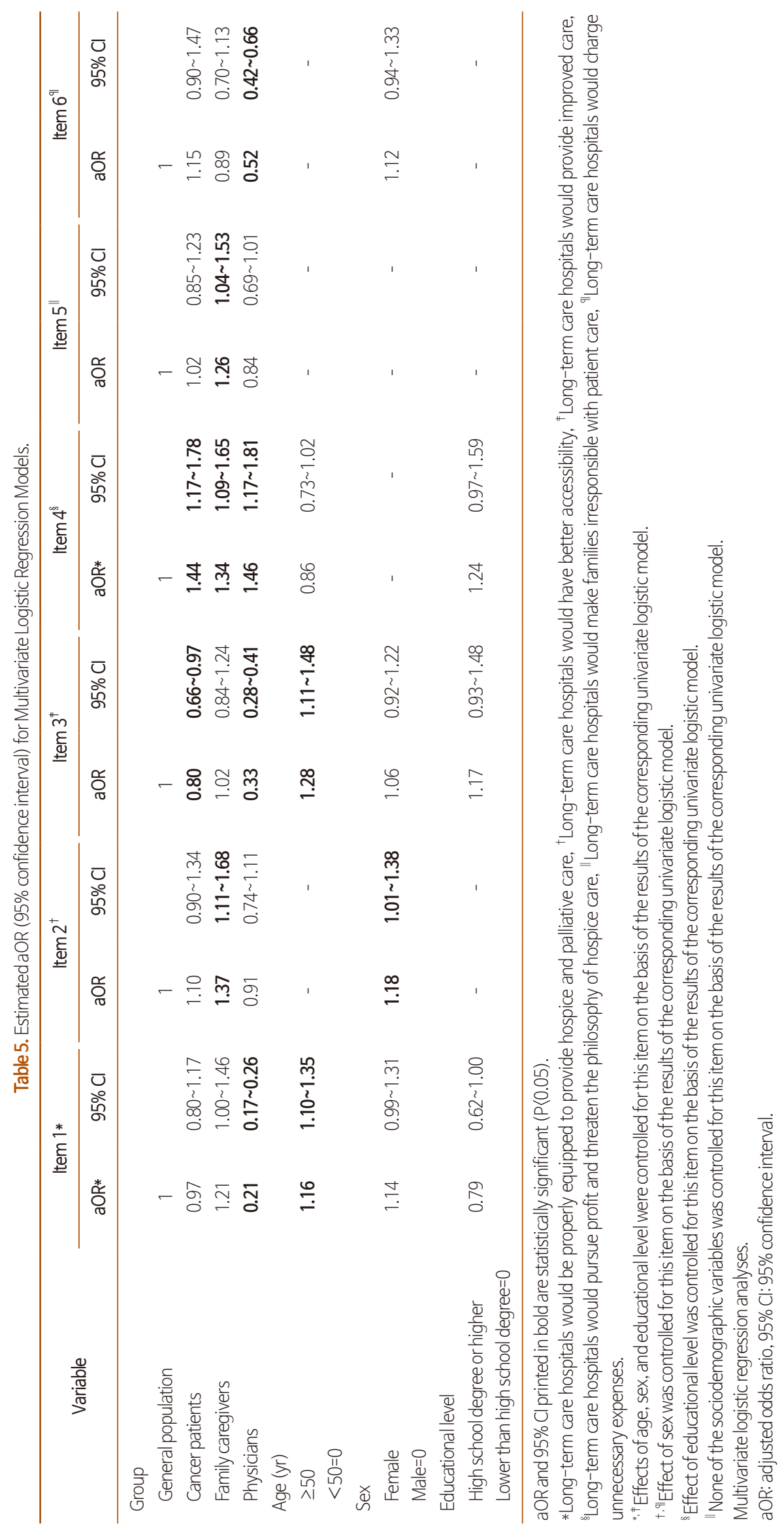


showed the most disagreement with this statement (item 4: $\left.\chi^{2}=18.73, \mathrm{df}=3, \mathrm{P}<0.001\right)$.

\section{Univariate and multivariate logistic regression}

The results of each univariate logistic regression model are shown in Table 4. The degree to which the participants agreed or disagreed with the potential benefits and risks of the amendment varied by group and sociodemographic characteristics. We selected the explanatory variables that were significantly associated with the response and included them in the subsequent multivariate logistic regression models.

Multivariate logistic regression analysis showed differences in the perception of the potential benefits and risks of the current amendment among the 4 groups even after adjusting for the effects of sociodemographic variables (Table 5). Compared with the general population, cancer patients agreed less with the statement that long-term care hospitals would provide improved care (item 3: $a \mathrm{OR}=0.80,95 \% \mathrm{CI}=0.66 \sim 0.97, \mathrm{P}$ $<0.05$ ), and they were more likely to agree that long-term care hospitals would pursue profit and threaten the philosophy of hospice care (item 4: aOR=1.44, 95\% CI=1.17 1.78, $\mathrm{P}<0.001$ ). Family caregivers were more likely to perceive better accessibility as a benefit of this amendment than the general population (item 2: $\mathrm{aOR}=1.37,95 \% \mathrm{CI}=1.11 \sim 1.68$, $\mathrm{P}<0.01)$; on the other hand, they were more likely to worry about the hospice philosophy being threatened in long-term care hospital settings (item 4: $\mathrm{aOR}=1.34,95 \% \mathrm{CI}=1.09 \sim 1.65$, $\mathrm{P}<0.01$ ) and families becoming irresponsible with patient care (item 5: $\mathrm{aOR}=1.26,95 \% \mathrm{CI}=1.04 \sim 1.53, \mathrm{P}<0.05$ ). Compared with the general population, physicians were less likely to agree that this setting is properly equipped to provide hospice and palliative care (item 1: $\mathrm{aOR}=0.21,95 \% \mathrm{CI}=0.17 \sim 0.26, \mathrm{P}$ $<0.001)$. Furthermore, similar to cancer patients and family caregivers, physicians were concerned that long-term care hospitals would pursue profit, which can threaten the hospice philosophy (item 4: $\mathrm{aOR}=1.46,95 \% \mathrm{CI}=1.17 \sim 1.81, \mathrm{P}<0.001$ ). Both results indicated that physicians expressed more concerns regarding the current amendment than the general population.

\section{DISCUSSION}

We examined how the Korean population perceives the new amendment to the Act on Hospice and Palliative Care and Decisions on Life-sustaining Treatment for Patients at the End of Life that designates long-term care hospitals as providers of hospice and palliative care. We compared the opinions of cancer patients, family caregivers, physicians, and the general population. Variances among the groups existed even after adjusting for sociodemographic confounders.

Overall, physicians perceived relatively more risks of the current amendment than the general population. Physicians were specifically concerned about a weak infrastructure, lowquality end-of-life care services, and a threat to the philosophy of hospice if long-term care hospitals become providers of hospice and palliative care. Such concerns are consistent with the findings of a previous study that examined the prevailing problems in this setting (2). Long-term care hospitals with the current staffing standard may not be able to meet the staff requirements for hospital palliative care facilities. Thus, it is plausible that an insufficient number of staff will result in a constant burnout issue, which in turn could hinder proper pain and symptom management in end-of-life patients. Our findings reflect that physicians were likely to worry about such realities of the current care settings in Korea. This concern about the insufficient resource infrastructure and their effects should be taken into account before the amendment takes effect.

Notably, compared with the general population, family caregivers found the issue of accessibility more favorable, whereas the results of cancer patients and physicians were not significantly different from those of the general population. Considering the reported positive association between the distance to a nursing home where patients are admitted and the burden experienced by their family caregivers (14), the result related to issue of accessibility may indicate that family caregivers feel a burden or even guilt concerning admitting their loved ones farther away. Ironically, however, they were more likely to agree that families would become irresponsible with patient care, which perhaps reflects the commonly held misconception that admitting relatives to hospice facilities indicates dumping them and ceasing to be involved in their lives (15). These fairly universal concerns of family caregivers can be addressed by including them in hospice and palliative care.

Compared with the general population, neither cancer patients nor family caregivers were worried that long-term care 
hospitals would charge them unnecessary expenses. We assume that the coverage of costs by the National Health Insurance Service may buffer the burden of expenses. However, both groups showed higher agreement that the hospice philosophy would be threatened if long-term care hospitals provide hospice and palliative care; moreover, patients were more concerned about the deterioration of quality of end-of-life service following the amendment. A previous study highlighted the role of prior awareness in shaping the attitudes of individuals toward medical services (16), and our findings address the prevailing distrust or skepticism of cancer patients and family caregivers toward the service provided by long-term care hospitals.

Taking the opinions of all groups together, an effective integration of hospice and palliative care into long-term care hospital settings can be achieved by facilitating organizational changes and supporting staff. Along with the recently enacted amendment, further policy directives, financial plans, or regulatory processes driven at national and regional levels should support provision of quality end-of-life care by longterm care hospitals. Apart from these national-level activities, Frogatt and colleagues pointed out that countries with greater evidence of meso-level activities (e.g., educational programs, quality assurance frameworks, and service development projects), such as Belgium and Denmark, are more likely to have a greater extent of organizational provision of palliative care in long-term care facilities (17). In this regard, the examples of the PACE Steps to Success or the Gold Standards Framework, which are palliative care interventions conducted at long-term care facilities in European countries, could provide insight into how to deliver a service more effectively $(18,19)$. It should be noted that these 2 trials aimed not only to train care staff but also to reform the organization as a whole and thereby improve end-of-life care by influencing the facilities' end-of-life culture, decision-making processes, and practices overall (19). This "complex" approach may also be applicable in Korea to prevent the problems discussed in the present study.

A couple of caveats of this study need to be noted. First, considering that we recruited cancer patients and family caregivers only from general hospitals, our findings are not generalizable despite the large sample size. Because one's socioeconomic status or place of residence may influence which hospital a cancer patient is placed, patients from the other levels of hospitals (e.g., primary and secondary hospitals) may express different opinions than those of the current sample. Second, we again emphasize that we dichotomized the variables for the present study because we focused on determining if there are differences in the extent to which our participants agreed or disagreed with the 6 statements concerning the amendment. Because such a method inevitably results in loss of information (20), one should be wary of any disadvantages of dichotomization when interpreting our findings. Despite these limitations, our study addresses the need to improve end-oflife care in Korea. Because the present findings are based on the opinions of potential beneficiaries and service providers of end-of-life care, we addressed the substantive issues related to the current amendment to the Act on Decisions on Lifesustaining Treatment; accordingly, we suggest how to resolve any potential problems following its enactment.

Designating long-term care hospitals as providers of hospice and palliative care will indeed increase the accessibility to care services. However, long-term care hospitals should take a holistic approach into account to deliver successful care services to patients nearing the end of life. Such an approach includes aspects of palliative and hospice care such as comprehensive comfort care, terminal care, and bereavement management. Because patients are placed in long-term care hospitals as a result of their condition from an earlier phase of disease, continuous care should be provided in this setting as well. Taken together, it is not only the accessibility that matters but also the quality of end-of-life care, which is vital. Instead of a simple increase in quantity, reformation of end-of-life care that emphasizes improvement in quality will eventually benefit service recipients and providers.

\section{ACKNOWLEDGEMENTS}

The authors would like to thank Ms. Shira Richman and Ms. Franziska Damm from Friedrich-Alexander University Erlangen-Nuremberg for English-language editing.

\section{요약}

목적: 호스피스 완화의료에의 접근성 향상을 위해 요양병원을 호스 
피스 전문기관으로 지정하는 개정안이 최근 시행되었다. 호스피스 전문기관의 양적 증대도 중요하지만, 이러한 개정에 따른 서비스의 질적 저하 역시 충분히 고려되어야 한다. 이러한 관점에서 본 연구는 1,001 명의 암환자, 1,006 명의 가족 간병인, 928 명의 의사 및 1,005 명의 일반인이 해당 개정안이 가진 이점과 비용에 대해 어떻게 인식 하고 있는지 확인하였다.

방법: 2016년 7월부터 10월까지 다기관 단면조사를 시행하였다. 연 구 참여자들은 전문가 인터뷰 및 선행연구에서 추출된 본 개정안의 이점과 비용에 대해 각각 얼마나 동의 혹은 동의하지 않는지 응답하 였다. 분석에는 카이제곱 분석, 단변량 및 다변량 로지스틱 회귀분석 을 활용하였다.

결과: 참조집단인 일반인 집단과 비교했을 때, 의사 집단은 요양병원 이 양질의 호스피스 완화의료 서비스를 제공하기 위한 시설 및 인력 이 충분하지 않다는 점에 더 동의하였으나, 요양병원에서 과한 진료 비를 청구할 것이라는 점에는 더 동의하지 않았다. 가족 간병인의 경
우 일반인에 비해 요양병원에서 서비스를 제공한다면 접근성이 좋 아질 것이라는 점에 더 동의했으나, 호스피스 정신이 훼손될 수 있음 과 가족들이 환자 돌봄에 신경 쓰지 않을 것을 더 우려하였다. 일반 인과 비교했을 때, 암환자 역시 마찬가지로 호스피스 정신이 훼손될 수 있음을 더 우려하였으며, 서비스의 질이 좋아질 것이라는 점에 대 해서는 더 동의하지 않았다.

결론: 본 연구를 통해 호스피스 완화의료의 잠재적인 서비스 이용자 및 제공자가 해당 개정의 이점뿐만 아니라 비용 역시 인식하고 있음 을 확인하였다. 본 연구 결과 및 유럽 국가들의 사례를 통해 개정안 이 실제로 현장에서 실행되기 전에 호스피스 전문기관으로서 요양 병원이 새롭게 갖추어야 할 요건 및 방향성에 대해 제언하였다.

중심단어: 호스피스 돌봄, 완화의료 돌봄, 생애말기 돌봄, 의료진, 가 족 간병인

\section{REFERENCES}

1. Lee SH, Shin DE, Sim JA, Yun YH. Public perception and acceptance of the national strategy for well-dying. Korean J Hosp Palliat Care 2013;16:90-7.

2. Seoul Cyber University R\&DB Foundation; Kwon KJ. A report on state of human rights in geriatric hospitals. Seoul:National Human Rights Commission of Korea;2014.

3. Chang YJ. The general palliative care system and the role of long-term care hospital. Research Institute for Healthcare Policy Korean Medical Association 2014;12:57-61.

4. Albers G, Harding R, Pasman HR, Onwuteaka-Philipsen BD, Hall S, Toscani F, et al. What is the methodological rigour of palliative care research in long-term care facilities in Europe? A systematic review. Palliat Med 2012;26:722-33.

5. Leclerc BS, Lessard S, Bechennec C, Le Gal E, Benoit S, Bellerose L. Attitudes toward death, dying, end-of-life palliative care, and interdisciplinary practice in long term care workers. J Am Med Dir Assoc 2014;15:207-13.

6. Hanson LC, Sengupta S, Slubicki M. Access to nursing home hospice: perspectives of nursing home and hospice administrators. J Palliat Med 2005;8:1207-13.

7. Park S. A study on the development for supply plan of palliative care facilities for terminally ill cancer patients. Goyang:National Cancer Center;Korea Health Industry Development Institute;2015.

8. Song H. Long-term care hospital systems in developed countries and the implications for Korea. J Korean Geriatr Soc 2012;16:114-20.

9. Choi I. A study on re-structuring role of LTC care facilities and geriatric hospital by user's need and region. J Community Welf 2014;50:13976.

10. Kweon K. Analysis on problems and remedies of a geriatric hospital [dissertation]. Seoul: Korea Univ.; 2015. Korean.

11. Kim JH. Development of activation plans and palliative care model for palliative care based on NHI (National Health Insurance) pilot project. Wonju:Health Insurance Review and Assessment Service; 2011.

12. Levy PS, Lemeshow S. Sampling of populations : methods and applications. New York (NY):Wiley;c1999.

13. Pasek J. Package 'weights'. Vienna:The Comprehensive R Archive Network;2018.

14. Tornatore JB, Grant LA. Burden among family caregivers of persons with Alzheimer's disease in nursing homes. Gerontologist 2002;42:497506.

15. Nolan M, Dellasega C. 'It's not the same as him being at home': creating caring partnerships following nursing home placement. J Clin Nurs 1999;8:723-30.

16. Jang Y, Chiriboga DA, Allen JY, Kwak J, Haley WE. Willingness of older Korean-American adults to use hospice. J Am Geriatr Soc 2010;58:352-6.

17. Froggatt K, Payne S, Morbey H, Edwards M, Finne-Soveri H, Gambassi G, et al. Palliative care development in European care homes and nursing homes: application of a typology of implementation. J Am Med Dir Assoc 2017;18: 550.e7-550.e14. 


\section{KJî̉PC}

End-of-Life Care Services Provided by Long-Term Care Hospitals

18. Smets T, Onwuteaka-Philipsen BBD, Miranda R, Pivodic L, Tanghe M, van Hout H, et al. Integrating palliative care in long-term care facilities across Europe (PACE): protocol of a cluster randomized controlled trial of the 'PACE Steps to Success' intervention in seven countries. BMC Palliat Care 2018;17:47.

19. Watson J, Hockley J, Murray S. Evaluating effectiveness of the GSFCH and LCP in care homes. End life Care J 2010; 4: 42-9.

20. MacCallum RC, Zhang S, Preacher KJ, Rucker DD. On the practice of dichotomization of quantitative variables. Psychol Methods 2001;7:1940. 